\title{
HUBUNGAN ANTARA SIKAP KOMUNIKATIF SEBAGAI BAGIAN DARI PENGEMBANGAN KARAKTER DENGAN KOMPETENSI INTI PENGETAHUAN IPS SISWA
}

\author{
Ni Wyn. Nik Lisa1, I Wyn. Sujana2, I Ngh. Suadnyana3
}

\begin{abstract}
1,2,3Jurusan Pendidikan Guru Sekolah Dasar, Universitas Pendidikan Ganesha, Singaraja, Indonesia e-mail :ni.wayan.nik.lisa@undiksha.ac.id ${ }^{1}$, iwayan.sujana@undiksha.ac.id ${ }^{2}$,inengah.suadnyana@undiksha.ac.id ${ }^{3}$
\end{abstract}

\begin{abstract}
Abstrak
Penelitian ini bertujuan untuk mengetahui hubungan antara sikap komunikatif sebagai bagian dari pengembangan karakter dengan kompetensi inti pengetahuan IPS siswa kelas V SD Gugus Letkol Wisnu Tahun Pelajaran 2017/2018.Jenis penilitian ini adalah penelitian ex post facto dengan studi korelasi yang bersifat asimetris.Populasi dari penelitian ini merupakan siswa kelas V SD yang berada di Gugus Letkol Wisnu, Denpasar Utara Tahun Pelajaran 2017/2018 dengan jumlah 340 orang.Penentuan sampel menggunakan teknik proporsional random sampling dengan taraf kesalahan $5 \%$ dan diperoleh sampel sebanyak 172 orang.Data diperoleh melaluimengisi angket sikap komunikatif oleh responden.Sebagai uji persyarat adalah uji normalitas sebaran data dan pencatatan dokumen dari nilai UAS kompetensi inti pengetahuan IPS siswa pada semester 1.Setelah seluruh uji prasyarat terpenuhi, analisis statistik yang digunakan pada penelitian ini adalah uji hipotesis menggunakan analisis korelasi product moment.Berdasarkan hasil analisis maka $r_{x y}$ hitung $=0,252$. Pada taraf signifikansi $5 \%$ dengan $\mathrm{n}=172$, maka diperoleh $r_{x y}$ tabel $=0,148$. Karena $r_{x y}$ hitung $=0,252>r_{x y}$ tabel $=0,148$ maka dapat diartikan bahwa Ho yang berbunyi tidak terdapat hubungan yang signifikan antara sikap komunikatif sebagai bagian dari pengembangan karakter dengan kompetensi inti pengetahuan IPS siswa kelas V SD Gugus Letkol Wisnu Tahun Pelajaran 2017/2018 ditolak sedangkan $\mathrm{Ha}$ diterima. Jadi dapat disimpulkan bahwa terdapat hubungan antara sikap komunikatif sebagai bagian dari pengembangan karakter dengan kompetensi inti pengetahuan IPS siswa kelas $V$ SD Gugus Letkol Wisnu, dengan arah korelasi positif, artinya semakin tinggi sikap komunikatif siswa maka semakin meningkatkan hasil kompetensi inti pengetahuan IPS.
\end{abstract}

Kata kunci: sikap komunikatif, kompetensi inti, IPS

\begin{abstract}
This study was aimedat determining the relation between communicative attitudes as part of character development with the core competence of social science knowledge of the fifth grade students of SD Gugus Letkol Wisnu in Academic Year 2017/2018. The type of this present study was ex post facto research design with asymmetric correlation. The population of this study were the fifth grade students ofelementary school in Gugus Letkol Wisnu, North Denpasarin Academic Year 2017/2018 which consisted of 340 people. The sample was determined by using proportional random sampling technique with 5\% error rate in which it was obtained 172 people as samples. The data were obtained through result of questionnaires of communicative attitude as part of character development which were filled out by respondents and document recording of UAS value of core competence of students' social scienceknowledge in semester 1. As the prerequisite test, it was used a normality test data distribution. After all prerequisite tests were completed, statistical analysis used in this research was hypothesis test by using correlation analysis of product moment. Based on the results of the analysis then $r_{x y \text { count }}=0,252$. At the significance level of $5 \%$ with $n=172$, then obtained $r_{x y t a b l e}=0,148$. Because $r_{x y c o u n t}=0,252>r_{x y t a b l e}=0,148$ hence, it could be interpreted that Ho which stated that there was no significant relation between communicative attitude as part of character development with core competence of social scienceknowledge of the fifth grade students of elementary school in Gugus Letkol Wisnu Academic Year 2017/2018 was denied,meanwhile Ha was accepted. So it could be concluded that there wassignificant correlation between communicative attitude as part of character development with core competence of social scienceknowledge of fifth grade students of elementary school Gugus Letkol Wisnu, with positive correlation direction, it meant that the higher communicative attitude of students increased the competency of social science.
\end{abstract}

Keywords : communicative attitude, core competence,social science knowledge 


\section{Pendahuluan}

Pendidikan mempunyai peranan yang sangat penting dalam membentuk karakter dalam diri seseorang. Berdasarkan Undang-Undang Nomor 20 tahun 2003 tentang Sistem Pendidikan Nasional, tujuan pendidikan nasional adalah mengembangkan potensi peserta didik agar menjadi manusia yang beriman dan bertakwa kepada Tuhan Yang Maha Esa, berakhlak mulia, sehat, berilmu, cakap, kreatif, mandiri, dan menjadi warga negara yang demokratis serta bertanggung jawab. Salah satu unsur terpenting dari keberhasilan suatu tujuan pendidikan adalah kurikulum. Perlu adanya kurikulum yang sesuai dan tepat agar tujuan pendidikan nasional tercapai secara maksimal dan tentunya terdapat pendidikan karakter. Tanpa kurikulum yang sesuai dan tepat, maka suatu tujuan dari pendidikan akan sulit dicapai.

Kurikulum yang serentak diterapkan hampir seluruh sekolah pada jenjang SD, SMP dan SMA/K di Denpasar, Bali adalah kurikulum 2013.Kurikulum 2013 merupakan aktualisasi kurikulum dalam pembelajaran dan pembentukkan kompetensi serta karakter siswa.Suyadi (2012) menyatakan untuk membangun bangsa dengan karakter utuh, dibutuhkan sistem pendidikan yang memiliki materi yang holistik, serta ditopang oleh pengelolaan dan pelaksanaan yang baik dan benar, dengan demikian pendidikan nasional harus bermutu dan berkarakter. "Karakter merupakan moralitas, kebenaran, kebaikan, kekuatan, dan sikap seseorang yang ditunjukkan kepada orang lain melalui tindakan" (Yaumi, 2014:7-8). Pendidikan karakter merupakan upaya terencana dalam proses pembimbingan dan pembelajaran bagi individu untuk mengembangkan karakter yang baik berdasarkan nilai-nilai inti yang baik untuk individu dan juga untuk masyarakat. Nilai-nilai yang dikembangkan pada pendidikan karakter diidentifikasi dari empat sumber, yakni agama, Pancasila, budaya dan tujuan pendidikan nasional.Berdasarkan keempat sumber nilai itu, teridentifikasi 18 nilai yang dapat dikembangkan melalui pendidikan budaya dan karakter bangsa, salah satunya adalah sikap komunikatif (Sulistyowati, 2012).

Bersahabat/ komunikatif merupakan sikap atau tindakan yang memperhatikan rasa senang berbicara, bergaul dan bekerjasama dengan orang lain (Narwanti, 2011). Sikap komunikatif berhubungan dengan orang lain yang di dalamnya terdapat komunikasi yang mudah dimengerti sehingga terwujud suasana yang menyenangkan dalam bekerjasama. Dalam pembelajaran di sekolah, sikap komunikatif ini dapat mempengaruhi kemampuan siswa dalam berdiskusi kelompok yang menuntut siswa harus mampu berkomunikasi yang baik dengan siswa lainnya sehingga dalam diskusi tersebut akan tercipta suasana yang aktif.

Melalui komunikasi, siswa dapat mendiskusikan, mengembangkan dan menyalurkan aspirasi serta pendapat-pendapat dalam bentuk lisan maupun tulisan.Dengan komunikasi pula, siswa dapat membangun pengetahuan baru hasil dari transformasi informasi yang diberikan oleh guru.Namun, pada kenyataannya siswa kurang mampu dalam mengkomunikasikan ide-ide yang ada dalam siswa. Siswa dapat menyelesaikan permasalahan yang diberikan guru, namun kadangkala tidak dapat menjelaskan hasil pemikirannya sendiri kepada siswa lain. Salah satu faktor penyebabnya yaitu guru lebih mendominasi pembelajaran daripada siswa, sehingga siswa bersifat pasif dan tidak memiliki kesempatan dalam menyampaikan berbagai ide yang dimiliki. Akibatnya, proses pembelajaran menjadi kurang komunikatif, padahal kemampuan komunikasi yang baik akan menghasilkan hasil belajar yang baik pula. Sehingga mengelola komunikasi yang efektif sangatlah penting karena dapat mengembangkan potensi peserta didik untuk mampu berpikir reflektif bagi penyelesaian masalah sosial di masyarakat.

IImu yang mengkaji tentang masalah sosial yang ada di masyarakat adalah IImu Pengetahuan Sosial atau yang sering disingkat dengan IPS.Menurut Susanto (2013) IPS merupakan ilmu pengetahuan yang mengkaji berbagai humaniora serta kegiatan dasar manusia yang dikemas secara ilmiah dalam rangka memberi wawasan dan pemahaman yang mendalam kepada peserta didik, khususnya di tingkat dasar dan menengah. Pendidikan IPS di SD biasanya mempelajari manusia dalam semua aspek kehidupan dan interaksi dalam masyarakat.Di dalam interaksi tersebut, perlu adanya komunikasi yang baik agar terciptanya suasana yang nyaman dan menyenangkan. 
Menurut Sulistyowati (2012) Implementasi sikap komunikatif di sekolah dikembangkan melalui pengalaman belajar dan proses pembelajaran yang bermuara pada pembentukan karakter dalam diri siswa. Sikap komunikatif dalam kegiatan belajar mengajar di kelas, dapat dikembangkan dengan menggunakan pendekatan terintegrasi dalam semua pembelajaran salah satunya adalah kompetensi inti pengetahuan IPS.Berdasarkan hasil observasi pada siswa kelas V SD Gugus Letkol Wisnu, rata-rata nilai kompetensi inti pengetahuan IPS masih perlu ditingkatkan.

Tujuan dari penelitian ini adalah untuk mengetahui hubungan yang signifikan antara sikap komunikatif sebagai bagian dari pengembangan karakter dengan kompetensi inti pengetahuan IPS siswa kelas V SD Gugus Letkol Wisnu Tahun Pelajaran 2017/2018.

\section{Metode}

Penelitian ini merupakan penelitian ex post facto dengan studi korelasional. Menurut Kerlinger (dalam Emzir, 2011:119) "penelitian ex post facto adalah penyelidikan empiris yang sistematis dimana ilmuan tidak mengendalikan variabel bebas secara langsung karena eksistensi dari variabel tersebut telah terjadi, atau karena variabel tersebut pada dasarnya tidak dapat dimanipulasi". "Dua buah gejala dikatakan mempunyai korelasi (correlation) adalah apabila setiap perubahan pada gejala yang satu selalu diikuti dengan perubahan pada gejala yang lain, di mana masing-masing perubahan tersebut terjadi secara proporsional". Kesimpulannya yaitu, korelasi merupakan bentuk analisis data dengan menganalisis dua buah variabel yang memiliki hubungan timbal balik yang terjadi secara proporsional.Variabel yang dimaksud adalah variabel bebas dan variabel terikat.Variabel bebas dalam penelitian ini adalah sikap komunikatif sebagai bagian dari pengembangan karakter, sedangkan variabel terikat dalam penelitian ini adalah kompetensi inti pengetahuan IPS.

Penelitian ini dilaksanakan di Gugus Letkol Wisnu Denpasar Utara.yang terdiri dari 7 sekolah. Ketujuh sekolah tersebut adalah SD Negeri 1 Peguyangan, SD Negeri 3Peguyangan, SD Negeri 5 Peguyangan, SD Negeri 6Peguyangan, SD Negeri 10 Peguyangan, SD Negeri 11 Peguyangan, SD Negeri 12Peguyangan.Populasi dari penelitian ini merupakan siswa kelas V SD Gugus Letkol Wisnu yang terdiri dari 340 siswa.Dalam penentuan sampel dapat dilihat pada tabel Issac and Michael.Dalam tabel tersebut dijelaskan tentang besarnya sampel yang diambil dari populasi dengan tingkat signifikansi $1 \%, 5 \%$, dan $10 \%$. Sesuai dengan tabel tersebut, dengan jumlah populasi di SD Gugus Letkol Wisnu Denpasar Utara sebanyak 340 siswa, jadi jumlah sampel yang diambil dengan tingkat signifikansi $5 \%$ adalah 172 siswa dari masing-masing sekolah sesuai dengan proporsi jumlah siswa dalam satu kelas.

Jumlah sampel pada SD Negeri 1 Peguyangan yaitu sejumlah 45, jumlah sampel pada SD Negeri 3 Peguyangan yaitu sejumlah 23, jumlah sampel pada SD Negeri 5 Peguyangan yaitu sejumlah 33, jumlah sampel pada SD Negeri 6 Peguyangan yaitu sejumlah 18, jumlah sampel pada SD Negeri 10 Peguyangan yaitu sejumlah 20, jumlah sampel pada SD Negeri 11 Peguyangan yaitu sejumlah 18, Jumlah sampel pada SD Negeri 12 Peguyangan yaitu sejumlah 15. Jadi total jumlah sampel yang diambil dari populasi berjumlah 172 siswa.

Pengambilan sampel menggunakan tekniksampling.Teknik sampling merupakan cara yang digunakan untuk menentukan sampel yang data dan objeknya menjadi representasi populasi. "Salah satu syarat utama dari sampel yang baik adalah bahwa sampel itu harus mengandung atau memiliki ciri-ciri ataupun sifat-sifat yang terdapat pada populasi" (Netra, 1974:10).Prosedur yang ditempuh dilakukan dengan jalan menentukan individu yang terdapat dalam masing-masing kategori populasi, sesuai dengan proporsi untuk dijadikan sampel penelitian. Populasi yang berjumlah 340 orang terdiri dari sembilan kategori atau kelas, maka teknik pengambilan sampel yang digunakan adalah teknik proporsional random samplingyang dilakukan dengan cararandom(acak) menggunakan undian nomor absen siswa.

Metode pengumpulan data yang digunakan untuk memperoleh data dari setiap sampel adalah teknik nontes.Sudijono (2005) menyatakan apabila menggunakan teknik nontes, penilaian atau evaluasi hasil belajar peserta didik dilakukan tanpa menguji peserta didik, 
melainkan dilakukan dengan melakukan pengamatan secara sistematis, melakukan wawancara, menyebarkan angket, dan memeriksa atau meneliti dokumen-dokumen.Teknik non tes yang digunakan pada penelitian ini yaitu instrumen angket (kuesioner) dan pencatatan dokumentasi.

Data sikap komunikatif sebagai bagian dari pengembangan karakter dikumpulkan menggunakan kuesioner (angket).Bentukangket yang digunakan adalah angket berstuktur dengan bentukjawabantertutup yang jawabannya telah tersedia dan respondenmenjawabsetiap pertanyaan dengan cara memilih alternatif jawaban yangtelahdisediakan. "Angket atau kuesioner dikatakan menggunakan item tertutup, apabila peneliti dalam hal ini menyediakan beberapa alternatif jawaban, yang cocok bagi responden" (Sukardi, 2003:77).Kuesioner (angket) tersebut terdapat pernyataan dengan masing-masing 4 pilihan yaitu Sangat Setuju (SS), Setuju (S), Tidak Setuju (TS) dan Sangat Tidak Setuju (STS). Adapun karakteristik sikap komunikatif yang dijadikan pedoman pembuatan kisi-kisi angket dalam peneltian ini adalah sebagai berikut. A. Senang belajar bersama dengan orang lain. b. Semakin banyak berinteraksi dengan orang lain, semakin merasa berbahagia dan termotivasi untuk belajar. C. Menunjukkan perkembangan yang luar biasa ketika belajar melalui pendekatan kooperatif dan kolaboratif. D.Berorganisasi merupakan cara terbaik untuk mengaktualisasi diri. E. Melibatkan diri dalam berbagai aktivitas yang melibatkan orang lain. F. Memiliki kepedulian dalam berbagai persoalan dan isu-isu sosial.

Pernyataan yang terdapat pada kuesioner sebanyak 30 pernyataan yang sesuai dengan kisi-kisi yang telah ditetapkan.Pengujian instrumen sikap komunikatif sebagai bagian dari pengembangan karakter yaitu menggunakan uji validitas diantaranya validitas isi dan konstrak.

Data kompetensi inti pengetahuan IPS diperoleh melalui pencatatan dokumen nilai UAS IPS siswa kelas V SD Letkol Wisnu Tahun Pelajaran 2017/2018.Setelah data sikap komunikatif sebagai bagian dari pengembangan karakter dan kompetensi inti pengetahuan IPS diperoleh, dilanjutkan dengan menganalisis data hasil penelitian.

Teknik analisis data yang digunakan dalam penelitian ini yaitu analisis statistik deskriptif dan analisis statistik inferensial.Pada statistik deskriptif juga dapat dilakukan mencari kuatnya hubungan antara variabel melalui analisis korelasi. Agung (2014) menyatakan pengolahan data pada analisis statistik deskriptif dilakukan dengan menggunakan rumus seperti: distribusi frekuensi, grafik, angka rata-rata, median, modus, mean dan standar deviasi, untuk menggambarkan suatu objek/variabel tertentu.Analisis statistik deskriptif pada penelitian ini menggunakan rata-rata (mean), median dan standar deviasi.

Metode analisis statistik inferensial yang dilakukan adalah menguji hipotesis.Uji hipotesis ini dilakukan setelah mendapatkan data tentang sikap komunikatif dan kompetensi inti pengetahuan IPS.Untuk memenuhi persyaratan pengujian hipotesisnya, diperlukan persyaratan analisis yaitu uji normalitas sebaran data.Setelah data berdistribusi normal dilanjutkan dengan analisis statistik inferensial menggunakan teknik korelasi product moment.

Adapun hipotesis yang diuji yaitu hipotesis nol $\left(H_{0}\right)$ yang berbunyi tidak terdapat hubungan yang signifikan antara sikap komunikatif sebagai bagian dari pengembangan karakter dengan kompetensi inti pengetahuan IPS siswa kelas V SD Gugus Letkol Wisnu Tahun Pelajaran 2017/2018.Ketentuan dari analisis product moment yang digunakan yaitu apabila hasil $r_{x y \text { hitung }}>r_{x y \text { tabel }}$ maka $\left(H_{0}\right)$ yang berbunyi tidak terdapat hubungan yang signifikan antara sikap komunikatif sebagai bagian dari pengembangan karakter dengan kompetensi inti pengetahuan IPS siswa kelas V SD Gugus Letkol Wisnu Tahun Pelajaran 2017/2018 ditolak dan hipotesis alternatif $\left(H_{a}\right)$ yang berbunyi terdapat hubungan yang signifikan antara sikap komunikatif sebagai bagian dari pengembangan karakter dengan kompetensi inti pengetahuan IPS siswa kelas V SD Gugus Letkol Wisnu Tahun Pelajaran 2017/2018 diterima. Sebaliknya apabila hasil $r_{x y \text { hitung }} \leq r_{x y \text { tabel }}$ maka $H_{0}$ diterima dan $H_{a}$ ditolak.

\section{Hasil dan Pembahasan}

Jurnal Mimbar IImu | 161 
Hasil penelitian ini memaparkan mengenai data sikap komunikatif sebagai variabel bebas (X) dan data kompetensi inti pengetahuan IPS sebagai variabel terikat $(\mathrm{Y})$ yang ditampilkan grafik.

Datasikap komunikatif sebagai bagian dari pengembangan karakter dapat dilihat dalam bentuk grafik berikut.

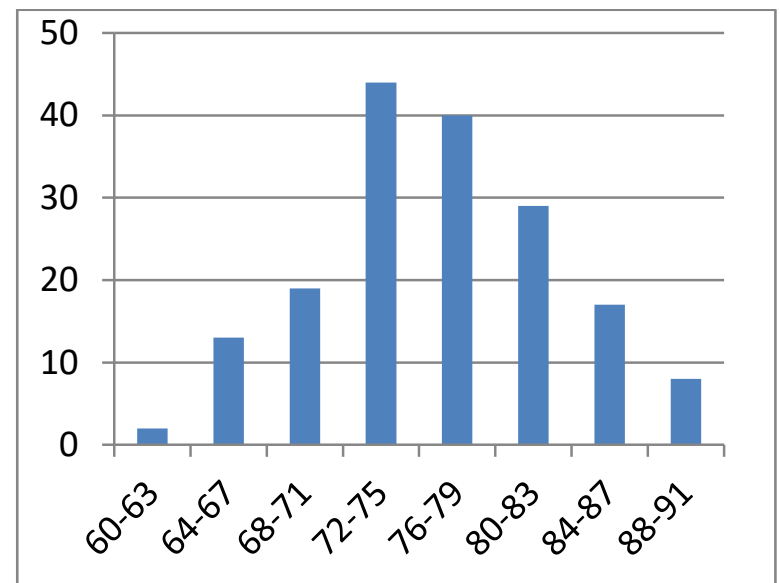

Gambar 1. Histogram Data Sikap Komunikatif Sebagai Bagian dari Pengembangan Karakter

Data sikap komunikatif sebagai bagian dari pengembangan karakter dapat diketahuibahwa nilai tertinggi $(X t)=91$, nilai terendah $(X r)=62$ dan standar deviasi $(s)=$ 6,32, serta rerata dari nilai sikap komunikatif siswa adalah 76,52 dan nilai tersebut berada pada nilai PAP rentang 65 - 79. Maka dapat disimpulkan bahwa sikap komunikatif siswa kelas V SD di Gugus Letkol Wisnu, Denpasar Utara tergolong cukup baik. berikut.

Kemudian data dari kompetensi inti pengetahuan IPS dapat dilihat dalam bentuk grafik

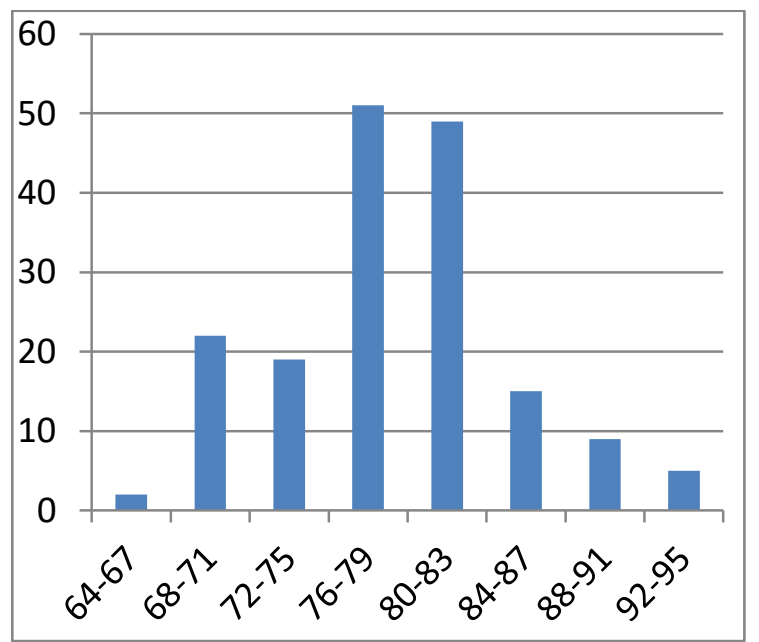

Gambar 2. Histogram Data Kompetensi Inti Pengetahuan IPS

Berdasarkan hasil analisis data sikap komunikatif sebagai bagian dari pengembangan karakter diketahui bahwa bahwa nilai tertinggi $(X t)=94$, nilai terendah $(X r)=$ 66 dan standar deviasi $(\mathrm{s})=5,93$, serta rerata dari nilai ilmu pengetahuan IPS siswa adalah 78,82 dan nilai tersebut berada pada nilai PAP rentang 65 - 79. Maka dapat disimpulkan bahwa kompetensi inti pengetahuan IPS siswa kelas V SD di Gugus Letkol Wisnu, Denpasar Utara tergolong cukup baik.

Langkah selanjutnya adalah uji prasyarat yaitu Uji Normalitas sikap komunikatif sebagai bagian dari pengembangan karakter dan kompetensi inti pengetahuan IPS pada siswa kelas V SD Gugus Letkol Wisnu menggunakan teknik uji Chi-Kuadrat $\left(x^{2}\right)$. 
Hasil uji normalitas sikap komunikatif sebagai bagian dari pengembangan karakter yaitu berdasarkan analisis diperoleh $x_{\text {hitung }}^{2}=3,46$, dan menggunakan taraf signifikan $5 \%$ diperoleh $x_{\text {tabel }}^{2}=11,07$ maka, $x_{\text {hitung }}^{2}=3,46<x_{\text {tabel }}^{2}=11,07$. Hal ini berarti $\mathrm{H}_{0}$ diterima, sehingga dapat disimpulkan bahwa sebaran data berdistribusi normal.

Hasil uji normalitas kompetensi inti pengetahuan IPS pada siswa kelas V SD Gugus Letkol Wisnu Denpasar Utara yaitu berdasarkan analisis diperoleh $x_{\text {hitung }}^{2}=4,39$, dan menggunakan taraf signifikan $5 \%$ diperoleh $x_{\text {tabel }}^{2}=11,07$ maka, $x_{\text {hitung }}^{2}=3,49<x_{\text {tabel }}^{2}=11,07$. Hal ini berarti $\mathrm{H}_{0}$ diterima, sehingga dapat disimpulkan bahwa sebaran data berdistribusi normal.

Setelah melalui uji normalitas dan data berdistribusi normal maka dilanjutnya dengan uji hipotesis yang dilakukan adalah uji hipotesis dengan teknik menggunakan analisis product moment (variabel $\mathrm{X}$ dengan $\mathrm{Y}$ )."Teknik korelasi Product Moment berfungsi untuk menghitung koefisien korelasi antara variabel bebas interval (skor) dengan variabel terikat interval (skor) lainnya" (Agung, (2016:125).Adapun langkah-langkah analisis korelasi product moment adalah sebagai berikut. 1. Merumuskan hipotesis nol, 2. Menyusun tabel kerja statistik 3Memasukkan data hasil kerja statistik ke dalam rumus, 3. Menguji harga statistik hasil penelitian, 4. Menarik kesimpulan

Hipotesisnol $\left(\mathrm{H}_{0}\right)$ yang dirumuskan pada penelitian ini berbunyi tidak terdapat hubungan yang signifikan antara sikap komunkiatif sebagai bagian dari pengembangan karakter dengankompetensi inti pengetahuan IPS siswa kelas V SD Gugus Letkol Wisnu tahun pelajaran 2017/2018. Rumus yang digunakan pada korelasi product moment adalah sebagai berikut.

$$
r_{x y}=\frac{N \sum X Y-\left(\sum X\right)\left(\sum Y\right)}{\sqrt{\left[N \sum X^{2}-\left(\sum X\right)^{2}\right]\left[N \sum Y^{2}-\left(\sum Y\right)^{2}\right]}}
$$

(Agung, 2016: 125)

Keterangan:

$\begin{array}{ll}r_{x y} & : \text { koefisien korelasi antara } \\ N & : \text { Jumlah Subjek } \\ X & : \text { Skor item } \\ Y & : \text { Skor total } \\ \sum X & : \text { Jumlah skor item } \\ \sum Y & : \text { Jumlah skor total } \\ \sum X^{2} & \text { : Jumlah kuadrat skor item } \\ \sum Y^{2} & \text { : Jumlah kuadrat skor total }\end{array}$

$X$ sebagai data-data dari variabel independent (variabel bebas)

Y sebagai data-data dari variabel dependent (variabel terikat).

Hasil analisis product moment bisa dilihat pada tabel 1.

Tabel 1. Analisis Product Moment

\begin{tabular}{cc}
\hline$\sum X$ & 13179 \\
$\sum Y$ & 13565 \\
$\sum X^{2}$ & 1016473 \\
$\sum X Y$ & 1075461 \\
$r_{x y}$ hitung & 1040928 \\
$r_{x y \text { tabel }}$ & 0,252 \\
\hline
\end{tabular}


Untuk uji signifikansi koefisien korelasi, digunakan nilai tabel product moment $(\mathrm{r}$ ) untuk $\mathrm{n}=172$, pada taraf signifikansi $5 \%$ diperoleh nilai $r_{x y}$ tabel adalah 0,148 sedangkan $r_{x y}$ hitung diperoleh hasil 0,252. Maka dapat dinyatakan $r_{x y h i t u n g}=0,252>r_{x y}$ tabel $=0,148$.

Berdasarkan hasil analisis penelitian yang diperoleh yaitu $r_{x y}$ huitung $>r_{x y}$ tabel sehingga $H_{0}$ yang berbunyi tidak terdapat hubungan yang signifikan antara sikap komunikatif sebagai bagian dari pengembangan karakter dengan kompetensi inti pengetahuan IPS siswa kelas V Sd Gugus Letkol Wisnu Tahun Pelajaran 2017/2018 ditolak sedangkan Ha yang berbunyi terdapat hubungan yang signifikan antara sikap komunikatif sebagai bagian dari pengembangan karakter dengan kompetensi inti pengetahuan IPS siswa kelas V Sd Gugus Letkol Wisnu Tahun Pelajaran 2017/2018 diterima. Berdasarkan uraian tersebut dapat mengemukakan interpretasi, berarti bahwa rata-rata siswa yang tergolong memiliki sikap komunikatif sebagai bagian dari pengembangan karakter, siswa akan memperoleh nilai yang lebih tinggi dalam pembelajaran serta memiliki wawasan yang luas dan minat yang tinggi dalam mengikuti pembelajaran.

Semakin tinggi sikap komunikatif yang dimiliki oleh siswa, maka semakin banyak wawasan yang dimiliki oleh siswa karena siswa dengan mudah menyampaikan ide atau gagasan yang dimiliki. Hal ini sesuai dengan penelitian Putri, dkk (2014:Vol.3) menyatakan perkembangan sikap komunikatif seseorang dapat dilihat dari siswa siswa yang lebih aktif bertanya maupun mengungkapkan pendapat dalam diskusi kelompok. Selain itu siswa juga terbiasa untuk saling bertanya kepada kepada siswa lain, mengungkapkan pendapat maupun menanggapi pendapat untuk menjawab pertanyaan. Sehingga apabila pembiasaan mengembangkan sikap komunikatif kepada siswa sudah terlaksana dan siswa mampu menumbuhkan sikap komunikatif dalam dirinya maka siswa akan lebih cepat memahami dan mampu menyelesaikan masalah-masalah yang ada dalam pembelajaran khususnya pada mata pelajaran IPS pada aspek kognitif.

Hal ini juga didukung oleh penelitian Aditya, dkk (2014:Vol.2) yang menyatakan berdasarkan hasil analisis data diperoleh $t_{\text {hitung }}$ sebesar 6,13 . Dengan taraf signifikansi $5 \%$ dan $\mathrm{dk}=66$ itu menunjukkan Ha diterima. Dapat diinterpretasikan bahwa terdapat perbedaan yang signifikan hasil belajar matematika siswa yang belajar melalui pembelajaran berbasis komunikatif berbantuan media animasi dengan siswa yang belajar melalui pembelajaran konvensional pada siswa kelas V SD Negeri Gugus V Kecamatan Karangasem Tahun Pelajaran 2013/2014.

Pada penelitian ini dperoleh $r_{x y}$ hitung $=0,252$ dengan $r_{x y}$ tabel pada taraf signifikan $5 \%$ adalah $\mathrm{n}=172$. Nilai $r_{x y}$ tabel untuk $\mathrm{n}=172$ adalah 0,148 . Hal ini berarti $r_{x y}$ hitung $>r_{x y}$ tabelyang berarti terdapat hubungan yang positif antara sikap komunikatif sebagai bagian dari pengembangan karakter dengan kompetensi inti pengetahuan IPS yang tergolong ke dalam kategori korelasi lemah. Hal tersebut disebabkan karena adanya faktor lain yang berhubungan dengan kompetensi inti pengetahuan IPS selain sikap komunikatif. Pencapaian kompetensi inti pengetahuan IPS merupakan keberhasilan siswa dalam belajar. Salah satu faktor lain yang dapat memengaruhi keberhasilan siswa dalam belajar adalah kecerdasan anak. Hal tersebut didukung oleh pendapat Susanto (2013) yaitu, faktor yang memengaruhi keberhasilan siswa belajar adalah kecerdasan anak, kesiapan anak dan bakat anak. Selain itu juga faktor yang memengaruhi tergantung pada guru, yaitu: kemampuan atau kompetensi, suasana belajar, dan kepribadian guru. Berdasarkan pendapat Susanto tersebut, keberhasilan siswa dalam belajar tergantung pada faktor dari dalam siswa dan faktor dari luar siswa.

Walaupun tergolong dalam kategori korelasi lemah, tetapi pengembangan sikap komunikatif dalam diri siswa harus dilaksanakan karena juga akan berdampak pada nilai kompetensi inti pengetahuan IPS siswa.

Sebagai implikasi dari hasil penelitian pada proses pembelajaran khususnya pembelajaran IPS, siswa kurang diberikan kesempatan dalam menyampaikan berbagai ide yang dimiliki karena guru lebih mendominasi pembelajaran daripada siswa. Dalam proses pembelajaran IPS masih terlihat pasif sehingga antusias siswa menurun, bahkan ada siswa yang berbicara sendiri, tidur, dan gaduh saat pelajaran berlangsung. Pembelajaran yang diberikan sebaiknya mampu membuat siswa lebih aktif dalam mengungkapkan ide atau 
gagasan dengan bahasa yang mudah dimengerti.Siswa dilatih untuk mampu mengomunikasikan pendapat dan juga mampu mencerna pendapat yang disampaikan oleh siswa lain. Melalui hal tersebut siswa akan mempunyai wawasan yang luas dengan mengembangkan sikap komunikatif yang dimiliki. Sikap komunikatif tersebut merupakan salah satu pendidikan karakter yang memang harus dikembangkan dalam diri siswa.

Siswa yang memiliki sikap komunikatif mampu percaya diri dalam mengomunikasikan ide atau gagasan yang dimiliki dalam proses pembelajaran di sekolah maupun di lingkungan sosial yang ada disekitarnya. Siswa yang memiliki sikap komunikatif, nantinya akan mampu menyelesaikan permasalahan yang ditemui dalam pembelajaran khususnya pada kompetensi inti pengetahuan IPS, karena berdasarkan hasil penelitian antara sikap komunikatif sebagai bagian dari pengembangan karakter memiliki hubungan yang positif.

\section{Simpulan dan Saran}

Hasil analisis menunjukkan bahwa terdapat hubungan yang signifikan antara sikap komunikatis sebagai bagian dari pengembangan karakter dengan kompetensi inti pengetahuan IPS Kelas V SD Gugus Letkol Wisnu Tahun Pelajaran 2017/2018.Katagori hubungan yang diperoleh termasuk hubungan yang lemah antara sikap komunikatif sebagai bagian dari pengembangan karakter dengan kompetensi inti pengetahuan IPS. Hal tersebut disebabkan karena adanya faktor lain yang berhubungan dengan kompetensi inti pengetahuan IPS.Sedangkan arah korelasi adalah positif karena nilai $r$ positif, berarti semakin tinggi sikap komunikatif siswa maka semakin tinggi pula hasil kompetensi inti pengetahuan IPS siswa.

Berdasarkan hasil analisis dengan menggunakan microsoft excel dan menghitung manual yang diperoleh $r_{x y \text { hitung }}=0,252$ dengan $r_{x y}$ tabel $=0,148$ yang memiliki arti $r_{x y}$ hitung $>r_{x y}$ tabel, sehingga $\mathrm{H}_{0}$ yang berbunyi tidak terdapat hubungan yang signifikan antara sikap komunikatif sebagai bagian dari pengembangan karakter dengan kompetensi inti pengetahuan IPS siswa kelas V SD Gugus Letkol Wisnu Tahun Pelajaran 207/2018 ditolak, sedangkan Ha yang berbunyi terdapat hubungan yang signifikan antara sikap komunikatif sebagai bagian dari pengembangan karakter dengan kompetensi inti pengetahuan IPS siswa kelas V SD Gugus Letkol Wisnu Tahun Pelajaran 207/2018 diterima.

Berdasarkan uraian tersebut dapat mengemukakan interpretasi, maka ini berarti bahwa rata-rata siswa yang tergolong memiliki sikap komunikatif sebagai bagian dari pengembangan karakter mampu meningkatkan nilai kompetensi inti pengetahuan IPS.Pengertian tersebut dapat diartikan, semakin tinggi sikap komunikatif siswa, maka semakin tinggi pula nilai kompetensi inti pengetahuan IPS siswa.Jadi dapat disimpulkan hubungan yang signifikan antara sikap komunikatif sebagai bagian dari pengembangan karakter dengan kompetensi inti pengetahuan IPS siswa memiliki korelasi dengan arah positif pada kategori lemah.

Berdasarkan hasil penelitian ini, maka dapat diajukan beberapa saran guna peningkatan kualitas pembelajaran yaitu:

Berdasarkan temuan penelitian yang diperoleh, disarankan kepada siswa agar lebih berani dalam menyampaikan ide atau gagasan. Kemampuan menyampaikan ide atau gagasan tersebut meningkatkan sikap komunikatif siswa dalam proses pembelajaran. Siswa memiliki sikap komunikatif dapat meningkatkan nilai kompetensi inti pengetahuan IPS siswa.

Berdasarkan temuan penelitian yang diperoleh, disarankan kepada guru agar dapat memberikan pembelajaran yang inovatif dan kolaboratif, karena pembelajaran yang kolaboratif akan membuat siswa terlatih dalam menyampaikan ide-ide yang mereka miliki dan juga lebih terampil dalam berkomunikasi yang baik dengan orang-orang yang ada di sekitarnya. Guru sebaiknya dapat menghilangkan rasa takut siswa dalam menyampaikan ide atau gagasan yang mereka miliki. Melalui hal tersebut nantinya siswa yang memiliki sikap komunikatif akan mampu menyelesaikan masalah-masalah yang ditemui pada kompetensi inti pengetahuan IPS.

Berdasarkan temuan penelitian, disarankan kepada kepala sekolah agar dapat menggunakan hasil penelitian ini sebagai pendukung sumber belajar guru dalam 
meningkatkan kualitas pembelajaran dengan menumbuhkan sikap komunikatif siswa di sekolah sehingga sekolah mampu menghasilkan siswa yang berkualitas.

Berdasarkan temuan penelitian, disarankan kepada peneliti agar hasil penelitian ini digunakan sebagai referensi untuk melaksanakan penelitian selanjutnya dan semoga penelitian ini bermanfaat bagi seluruh elemen masyarakat yang menggunakan penelitian ini.

\section{Daftar Pustaka}

Aditya, Budi, dkk. 2014. "Pembelajaran Berbasis Komunikatif Berbantuan Media Animasi Berpengaruh Terhadap Hasil Belajar Matematika Siswa Kelas V SD Negeri Gugus V Kecamatan Karangasem". Volume 3, Nomer 1. (diakses pada tanggal 19 Januari 2018). https://ejournal.undiksha.ac.id/index.php/JJPGSD/article/view/2151/1869

Agung, A. A. A G. 2014.Metode Penelitian Pendidikan. Yogyakarta: Aditya Media Publishing.

Agung, A. A. A G. 2016.Statistika Dasar untuk Pendidikan.Yogyakarta: CV Budi Utama.

Emzir. 2011. Metodologi Penelitian Pendidikan: Kuantitatif dan Kualitatif. Jakarta: PT RajaGrafindo Persada..

Netra, I. B. 1974. Statistik Inferensial. Surabaya: Usaha Nasional.

Putri, dkk. 2014. "Penerapan Model Pembelajaran Kontekstual Dengan Pendekatan Snowball Throwing Untuk Mengembangkan Karakter Komunikatif dan Rasa Ingin Tahu Siswa Smp".Volume 3, Nomor 1 (hlm. 5). (diakses pada tanggal 19 Januari 2018). http://journal.unnes.ac.id/sju/index.php/upej

Sudijono. 2005. Pengantar Evaluasi Pendidikan. Jakarta: PT RajaGrafindo Persada.

Sukardi. 2012. Metodologi Penelitian Pendidikan. Jakarta: PT Bumi Aksara.

Sulistyowati, Endah. 2012. Implementasi Kurikulum Pendidikan Karakter. Yogyakarta: PT Citra Aji Parama.

Susanto, Ahmad. 2013. Teori Belajar dan Pembelajaran di Sekolah Dasar.Jakarta: Kencana.

Suyadi. 2012. Menerapkan Pendidikan Karakter di Sekolah. Yogyakarta: Mentari Pustaka.

Undang-Undang Republik Indonesia No. 20 Tahun 2003 tentang Sistem Pendidikan Nasional. 1999. Jakarta: PT. Arnas Duta Jaya.

Yaumi, Muhambad. 2014. Pendidikan Karakter: landasan, Pilar, dan Implementasi. Jakarta: Kencana 